сопротивления заполнения вращению. Показано, что невыполнение условий устойчивости движения может быть вызвано достижением экстремальных отрицательных значений производных от инерционных параметров внутрикамерного заполнения по угловой скорости вращения барабана.

Практическая значимость. Разработанная математическая модель позволяет качественно определять условия устойчивого вращательного движения барабана с текучим заполнением камеры. Условия возникновения неустойчивого движения имеют существенное прикладное значение, поскольку вызы- вают самовозбуждение автоколебаний заполненного барабана и определяют повышение эффективности процесса измельчения в барабанных мельницах традиционных конструктивных решений.

Ключевые слова: устойчивое вращение, барабан с текучим заполнением, уравнение невозмущенного вращения, уравнение переходного движения, условие асимптотической устойчивости, факторы неустойчивости, переменные инерционные параметры

Рекомендовано до публікації докт. техн. наук В.Й. Сівком. Дата надходження рукопису 16.11.16.

P. Ya. Pukach, Dr. Sc. (Tech.), Assoc. Prof., orcid.org/0000-0002-0359-5025, I. V. Kuzio, Dr. Sc. (Tech.), Prof., orcid.org/0000-0001-9271-6505, Z. M. Nytrebych, Dr. Sc. (Phys.-Math.), Prof., orcid.org/0000-0002-9599-8517, V.S. Il'kiv, Dr. Sc. (Phys.-Math.), Prof., orcid.org/0000-0001-6597-1404

\title{
ASYMPTOTIC METHOD FOR INVESTIGATING RESONANT REGIMES OF NONLINEAR BENDING VIBRATIONS OF ELASTIC SHAFT
}

П. Я. Пукач, д-р техн. наук, доц., orcid.org/0000-0002-0359-5025,

I. В. Кузьо, д-р техн. наук, проф., orcid.org/0000-0001-9271-6505,

3. М. Нитребич, д-р фіз.-мат. наук, проф., orcid.org/0000-0002-9599-8517,

В. С. Ільків, д-р фіз.-мат. наук, проф., orcid.org/0000-0001-6597-1404
Національний університет „Львівська політехніка““, м. Львів, Україна, e-mail: ppukach@i.ua

\section{АСИМПТОТИЧНИЙ МЕТОД ДОСЛІДЖЕННЯ РЕЗОНАНСНИХ РЕЖИМІВ НЕЛІНІЙНИХ ЗГИНАЛЬНИХ КОЛИВАНЬ ПРУЖНОГО ВАЛА}

Purpose. To develop a method for determining resonant modes of industrial equipment of elastic shaft type, which is widely used in the mining industry, through the study of mathematical model of nonlinear oscillations. Mathematical models of oscillatory systems previously were studied in the literature mainly based on the numerical and experimental approaches. This paper proposes using a combination of the wave theory of motion and asymptotic methods of nonlinear mechanics using special apparatus of periodic functions to investigate the vibrational dynamics of the system and conditions of resonance phenomena in it, as well as to describe the method for determining the resonance curves to increase the margin of safety of industrial equipment.

Methodology. Methods for studying resonance amplitudes and frequencies, determining the strength characteristics of equipment are based on the use of asymptotic methods of nonlinear mechanics, wave motion theory and theory of special Ateb-functions.

Findings. In this work the conditions of resonance amplitude and frequency depending on the system parameters were obtained analytically for these nonlinear vibrational systems of elastic shaft and the overall method for determining the resonance curves was described.

Originality. For the first time a complete analysis of the impact of physical, mechanical and geometrical factors of the dynamic pricess on the resonant frequency and amplitude in systems such as elastic shaft was conducted on the 
basis of analytical approaches that allow, in contrast to numerical methods and experimental approaches, exploring features of dynamics of such systems more precisely.

Practical value. The proposed technique allows solving important practical problems of developing oscillatory engineering systems at the design stage, selecting the elastic characteristics of shafts, counting modes and screw drilling equipment in view of possible resonance phenomena. Determination of resonance modes of the equipment in turn allows for efficient and safe mining.

Keywords: mathematical model, nonlinear vibrations, asymptotic method, elastic shaft, resonance curve, special function

Introduction. The relevance of the topic and analysis of the recent research. Mathematical models used in modeling modern machines, equipment and mechanisms of mining engineering, aviation, transport and space technology are becoming increasingly complex and improved. This is due to the increasing demands of power, speed and precision equipment [1-4]. The investigation of nonlinear mechanical systems with distributed parameters basing on the single-frequency vibrations principle and asymptotic methods of nonlinear mechanics was summarized on quasi-linear partial differential equations. Using these types of equations, which describe longitudinal and bending vibrations of single-dimensional systems with distributed parameters (rods, shafts, beams, etc.) with the elasticity principle close to linear, a number of important applied problems were solved. Nowadays, the use of asymptotic methods of nonlinear mechanics for investigating non-stationary dynamic processes in nonlinear mechanical systems with distributed parameters, are fully justified. Based on such methods, a lot of theoretical and practical problems of the vibration theory were solved, such as: non-stationary turbine machines rotor vibrations while crossing the critical number of revolutions; longitudinal and transverse vibrations of nonlinear elastic rods; rod vibrations under the axial and transverse load. The wave theory of motion has been widely used in the past few decades for investigating dynamical processes in different mediums and systems. In particular, in paper [5], the method for determining the optimal working mode of vibration protection equipment is developed.

The main ideas of the wave theory are widely used in applied problems, where it is not always possible to use classical methods, such as Fourier or D'Alambert methods for integrating partial differential equations. In particular, the D'Alambert method has been modified and generalized for use in nonlinear elastic systems, which vibrate in longitudinally movable mediums. The relevance of developing solving methods basing on the combination of the wave theory of motion and the asymptotic approach is mainly related to problems, which describe the dynamical processes of longitudinally movable mediums. For example, the longitudinal and transverse vibrations of belt, fluid pipe networks, auger machines in viscous or loose mediums, the vibroseparation process to some extent, and others. Besides, not only the quantitative characteristics of the process are influenced by the longitudinal part of the medium velocity, but also the qualitative characteristics, which may lead to vibration or stability failures.

In this paper, a method for investigating some classes of the upmentioned systems, namely, elastic bodies, which rotate around a fixed axis with constant angular velocity (drilling colons, auger machines, etc.) in a flow of me- dium is developed. The developed method is based on the ideas of asymptotic integration of partial differential equations, which combine the main principles of the wave theory of motion and the single-frequency vibrations principle in nonlinear systems. The bending vibrations of a single-dimensional elastic body, considering its angular velocity around a fixed axis and the relative motion in a flow of homogeneous medium, are investigated. The equation, which determines the main nonlinear vibration parameters, is obtained in standard form.

The dynamics of an elastic body in a continuous flow of homogeneous medium (CFHM) has not been properly investigated yet, mainly because of the lack of analysis methods, even for the linear mathematical models. However, the equipment, operation of which is described by such mathematical models, is widely used in various industries (mostly in mining industry). This fact has led to the development of different analytic and numerical methods for investigating both linear and nonlinear models of such systems in the past few decades. For partial solving of the problems, pointed in this paper, the following approach is proposed: the relative momentum of the medium is small compared to the momentum of the elastic body at its bending vibrations (small density or relative motion velocity of the medium); the relative motion velocity of the continuous flow of medium alongside the body is changing slowly.

The mathematical model of bending vibrations of an elastic body in a CFHM. For investigating the influence of the continuous flow of homogeneous medium on the nonlinear vibrations of an elastic body, firstly, a solution for the perturbated boundary problem

$$
\frac{\partial^{2} u}{\partial t^{2}}+\beta^{2} \frac{\partial^{2} u}{\partial x^{2}}+\alpha^{2} \frac{\partial^{4} u}{\partial x^{4}}=\varepsilon F\left(u, \theta, \frac{\partial u}{\partial t}, \frac{\partial^{2} u}{\partial x^{2}}, \frac{\partial^{3} u}{\partial x^{3}}, \frac{\partial^{4} u}{\partial x^{4}}\right)
$$

must be built. Here, $F\left(u, \theta, \frac{\partial u}{\partial t}, \frac{\partial^{2} u}{\partial x^{2}}, \frac{\partial^{3} u}{\partial x^{3}}, \frac{\partial^{4} u}{\partial x^{4}}, \theta\right)$ is an analytic $2 \pi-$ periodic function by the variable $v t=\theta$;

$$
\begin{gathered}
\beta^{2}=\frac{N-m_{1} V^{2}}{m+m_{1}} \\
\varepsilon F\left(u, \theta, \frac{\partial u}{\partial t}, \frac{\partial^{2} u}{\partial x^{2}}, \frac{\partial^{3} u}{\partial x^{3}}, \frac{\partial^{4} u}{\partial x^{4}}\right)=-\varepsilon \frac{E I}{m+m_{1}} \frac{\partial^{2}}{\partial x^{2}}\left(\frac{\partial^{2} u}{\partial x^{2}}\right)^{3}- \\
-\frac{m_{1}}{m+m_{1}} 2 V \frac{\partial^{2} u}{\partial x \partial t}+\frac{m_{1}}{m+m_{1}} q(x, t) .
\end{gathered}
$$

In the expressions above, $m$ is the linear mass of the elastic body; $m_{1}$ is the mass of a standard unit of the CFHM material line, which moves alongside the body; $E$ is the 
modulus of the body material elasticity; $I$ is the moment of inertia of the body's cross-section, relative to the neutral axis in non-deformed state (this axis is perpendicular to the vibration plane); $V$ is the constant speed of the medium movement along the continuum elastic body; $N$ is the pressure force; $q(x, t)$ is the intensity of the resultant of external forces which act on the body's standard unit. The equation (1) is complemented by boundary conditions, which correspond to the movement conditions of an elastic body at $x=0$ (the beginning) and $(x=l)$ (the end). Assuming the movement conditions as a fixed hinge, we have the following

$$
u(0, t)=u(l, t)=0 ; \quad \frac{\partial^{2} u}{\partial x^{2}}(0, t)=\frac{\partial^{2} u}{\partial x^{2}}(l, t)=0 .
$$

The solving of the problem $(1,2)$ simplifies the conditions, imposed on the right part of the statement (1), namely the maximum value of the force of inertia of the CFHM is small compared to $\max \alpha^{2} \frac{\partial^{4} u}{\partial x^{4}}$. This is also the pre-condition of applying the general ideas of perturbation methods for solving the up-mentioned boundary problem. In the first asymptotic approximation, the singlefrequency process of the elastic body is described as follows

$$
\begin{gathered}
u(x, t)=a(\cos (\kappa x+\psi)-\cos (\kappa x-\psi))+ \\
+\mu u_{1}(a, x, \psi, \theta), k=0,1,2, \ldots
\end{gathered}
$$

where $\psi=\omega t+\phi$. For the case under consideration, the $a$ and $\phi$ parameters are time-dependent functions, $u_{1}(a, \psi$, $\theta, x)$ is a $2 \pi-$ periodic function by the $\psi$ and $\theta$, which is defined from the fact that the asymptotic representation of the solution must satisfy the given equation and boundary conditions with the second order of accuracy.

Resonant vibrations of an elastic body in a CFHM. In this paper, the resonant case of bending vibrations of an elastic body in a continuous flow of medium is considered. Resonant vibrations are mostly a negative factor in mechanical systems, because of the significant increase in the vibration amplitude in case of resonance, and the increase in dynamic loads. This leads to the decrease of the system's exploitation resource.

Considering the nonlinear transverse vibrations of an elastic body in a CFHM, the physical, mechanical, and motion characteristics of the body affect not only the amplitude of the vibrations, but also the resonance frequency. For investigating the influence of the vibrations on the resonant value of the amplitude, the solution of the problem is sought the same way as in the non-resonance case, as an asymptotic representation (3), with the difference that, in resonant case, the vibration amplitude depends on the free and forced vibrations phase difference (parameter $\phi=\psi-\theta$ ). Taking this into account, in the asymptotic representation, the amplitude parameter is defined by a more complex formula

$$
\frac{d a}{d t}=\mu A_{1}(a, \phi) ; \quad \frac{d \phi}{d t}=\omega-v+\mu B_{1}(a, \phi) .
$$

The unknown functions $A_{1}(a, \phi)$ and $B_{1}(a, \phi)$ are found so that the asymptotic representation (3), taking into account (4), satisfies the given equation with the considered order of accuracy. To achieve this, by differentiating (4), we have the following

$$
\begin{gathered}
\frac{\partial u}{\partial t}=\varepsilon A_{1}(a, \phi)(\cos (\kappa x+\psi)-\cos (\kappa x-\psi))- \\
-a\left(\omega+\mu B_{1}(a, \phi)\right)(\sin (\kappa x+\psi)+\sin (\kappa x-\psi))+ \\
+\mu \frac{\partial u}{\partial \theta} \nu+\mu \frac{\partial u}{\partial \psi} \omega ; \\
\frac{\partial^{2} u}{\partial t^{2}}=\varepsilon \frac{\partial A(a, \phi)}{\partial \phi}(\omega-v)(\cos (\kappa x+\psi)-\cos (\kappa x-\psi))- \\
-2 \varepsilon \omega A_{1}(a, \phi)(\sin (\kappa x+\psi)+\sin (\kappa x-\psi))- \\
-a\left(\omega^{2}+2 \varepsilon \omega B_{1}(a, \phi)\right)(\cos (\kappa x+\psi)-\cos (\kappa x-\psi))- \\
-\varepsilon a \frac{\partial B_{1}(a, \phi)}{\partial \phi}(\omega-v)(\sin (\kappa x+\psi)+\sin (\kappa x-\psi))+ \\
+\frac{\partial^{2} u}{\partial \psi^{2}} \omega^{2}+\frac{\partial^{2} u}{\partial \theta^{2}} v^{2}+2 \frac{\partial^{2} u}{\partial \theta \partial \psi} v \omega .
\end{gathered}
$$

These formulas allow constructing a differential equation, which connects the sought functions in the following form

$$
\begin{gathered}
\frac{\partial^{2} u_{1}}{\partial \psi^{2}} \omega^{2}+2 \frac{\partial u_{1}}{\partial \psi \partial \theta} v \omega+v^{2} \frac{\partial^{2} u_{1}}{\partial \theta^{2}}+ \\
+\alpha^{2}\left(\frac{k \pi}{l}\right)^{4} \frac{\partial^{4} u_{1}}{\partial x^{4}}=a V^{2}\left(\frac{k \pi}{l}\right)^{2} \sin \frac{k \pi}{l} x \cos \psi- \\
-2 V \frac{k \pi}{l} \cos \frac{k \pi}{l} x \cos \psi+F(x, a, \psi, \theta)+ \\
+\mu \sin \frac{k \pi}{l} x\left(\cos \psi\left(-\frac{\partial A(a, \phi)}{\partial \phi}(\omega-v)+2 a \omega B\right)+\right. \\
\left.+\sin \psi\left(a \frac{\partial B(a, \phi)}{\partial \phi}(\omega-v)+2 A(a, \phi) \omega\right)\right)
\end{gathered}
$$

The unknown function satisfies the homogeneous (non-perturbated) conditions, if it can be presented as a series

$$
u_{1}(x, a, \psi, \theta)=\sum_{m} \sin \frac{s \pi}{l} x U_{1 m}(a, \theta, \psi) .
$$

In this case, the series coefficients are connected by differential equations:

a) if $k=1-$

$$
\begin{aligned}
& \frac{\partial^{2} u_{11}}{\partial \psi^{2}} \omega^{2}+2 \frac{\partial u_{11}}{\partial \psi \partial \theta} v \omega+v^{2} \frac{\partial^{2} u_{11}}{\partial \theta^{2}}+\alpha^{2}\left(\frac{\pi}{l}\right)^{4} u_{11}= \\
& =a V^{2}\left(\frac{\pi^{2}}{2 l}\right) \cos \psi+\frac{1}{p} \int_{0}^{l} F(a, x, \theta, \psi) X_{1}(x) d x+
\end{aligned}
$$

ISSN 2071-2227, Науковий вісник НГУ, 2018, № 1 


$$
\begin{gathered}
+\cos \psi\left(-\frac{\partial A(a, \phi)}{\partial \phi}(\omega-v)+2 a \omega B\right)+ \\
+\sin \psi\left(a \frac{\partial B(a, \phi)}{\partial \phi}(\omega-v)+2 A(a, \phi) \omega\right)
\end{gathered}
$$

b) if $k \neq 1-$

$$
\begin{aligned}
& \frac{\partial^{2} u_{1 k}}{\partial \psi^{2}} \omega^{2}+2 \frac{\partial u_{1 k}}{\partial \psi \partial \theta} v \omega+v^{2} \frac{\partial^{2} u_{1 k}}{\partial \theta^{2}}+\alpha^{2}\left(\frac{k \pi}{l}\right)^{4} u_{1 k}= \\
= & a V^{2} \frac{(k \pi)^{2}}{2 l} \cos \psi+\frac{1}{p} \int_{0}^{l} F(a, x, \theta, \psi) X_{S}(x) d x, p=\frac{l}{2} .
\end{aligned}
$$

By imposing conditions, which are analogical to the non-resonant case, on the function $u_{1 k}(a, \psi, \theta)$, for the main resonance we have the following

$$
\begin{gathered}
(\omega-v) \frac{\partial A}{\partial \phi}-2 a \omega B=\frac{1}{p} \frac{1}{4 \pi^{2}} \times \\
\times \sum_{s} e^{i s \phi} \int_{0}^{l} \int_{0}^{2 \pi} \int_{0}^{2 \pi} F(a, x, \psi, \theta) \sin \frac{k \pi}{l} x e^{-i s \phi} \cos \psi d x d \psi d \theta \\
a \frac{\partial B}{\partial \phi}(\omega-v)-2 A \omega+V^{2} \frac{\pi^{2}}{l^{2}}=\frac{1}{p} \frac{1}{4 \pi^{2}} \times \\
\times \sum_{s} e^{i s \phi} \int_{0}^{l} \int_{0}^{2 \pi} \int_{0}^{2 \pi} F(a, x, \psi, \theta) \sin \frac{k \pi}{l} x e^{-i s \phi} \cos \psi d x d \psi d \theta .
\end{gathered}
$$

Thereby, in case of resonance, for the first approximation of the solution of the problem we have a differential equation system, which connects the sought functions in the following form

$$
\begin{gathered}
(\omega-v) \frac{\partial^{2} a}{\partial t \partial \phi}-2 a \omega \frac{\partial \phi}{\partial t}=\frac{1}{p} \frac{1}{4 \pi^{2}} \times \\
\times \sum_{s} e^{i s \phi} \int_{0}^{l} \int_{0}^{2 \pi} \int_{0}^{2 \pi} F(a, x, \psi, \theta) \sin \frac{k \pi}{l} x e^{-i s \phi} \cos \psi d x d \psi d \theta \\
(\omega-v) a \frac{\partial^{2} \phi}{\partial t \partial \phi}-2 a \frac{\partial a}{\partial \phi}+V^{2} a \frac{\pi^{2}}{l^{2}}=\frac{1}{p} \frac{1}{4 \pi^{2}} \times \\
\times \sum_{s} e^{i s \phi} \int_{0}^{l} \int_{0}^{2 \pi} \int_{0}^{2 \pi} F(a, x, \psi, \theta) \sin \frac{k \pi}{l} x e^{-i s \phi} \cos \psi d x d \psi d \theta
\end{gathered}
$$

In the following paragraphs, based on general dependencies, the transverse vibrations of an elastic body in a continuous flow of medium under periodic harmonic perturbation, is considered. This case is the most interesting both theoretically and practically.

Transverse vibrations of an elastic body in a CFHM under harmonic perturbation, excluding the pressure force. In this case, the differential equation of the bending vibrations of an elastic body takes the following form

$$
\frac{\partial^{2} u}{\partial t^{2}}+\alpha^{2} \frac{\partial^{4} u}{\partial x^{4}}=-\frac{m_{1}}{m+m_{1}}\left(\frac{\partial^{2} u}{\partial x^{2}} V^{2}+2 \frac{\partial^{2} u}{\partial x \partial t} V\right)-
$$

$$
\begin{gathered}
-\varepsilon \frac{3 E I}{m+m_{1}} \frac{\partial^{2} u}{\partial x^{2}}\left[\frac{\partial^{2} u}{\partial x^{2}} \frac{\partial^{4} u}{\partial x^{4}}+2\left(\frac{\partial^{3} u}{\partial x^{3}}\right)^{2}\right]+ \\
+\varepsilon \frac{H}{m+m_{1}} \sin v t
\end{gathered}
$$

Assuming that the boundary conditions of the equation (5) correspond to the hinge-fixed body ends, the single-frequency vibration process, with the regime, close to the frequency of external perturbation, can be described by (3). The $a$ and $\varphi$ parameters for this case are determined by a differential equation system:

- for non-resonance case it is a system of the form (4);

- for the main resonance case -

$$
\begin{gathered}
\frac{d a}{d t}=-\frac{2 \varepsilon H}{\pi(\omega+v(t))} \cos \phi ; \\
\frac{d \phi}{d t}=\omega-v-\left(\frac{\pi}{l}\right)^{2} \frac{V^{2}}{8 \omega}+ \\
+\varepsilon\left(\frac{2 H}{\pi(\omega+v(t)) a} \sin \phi-\frac{3}{32} \frac{\pi^{2}}{l^{2}} \frac{a^{2}}{\omega}\right) .
\end{gathered}
$$

If an internal friction force, which is proportional to the velocity raised to the power $s$, namely $R=\gamma\left(\frac{\partial u}{d t}\right)^{s}$, where $\gamma$ is a constant, and the compression or stretching force is considered, then, the resonant and non-resonant vibrations can be described by the following dependencies

$$
\begin{gathered}
\frac{d a}{d t}=-\frac{\gamma}{m+m_{1}}(\bar{\omega})^{s-1} a^{s} ; \\
\frac{d \psi}{d t}=\bar{\omega}-\varepsilon\left(\frac{3}{32} \frac{\pi^{2}}{l^{2}} \frac{a^{2}}{\bar{\omega}}+\left(\frac{\pi}{l}\right)^{2} \frac{V^{2}}{8 \bar{\omega}}\right),
\end{gathered}
$$

or

$$
\begin{gathered}
\frac{d a}{d t}=-\frac{\beta}{m+m_{1}}(\bar{\omega})^{s-1} a^{s}+\frac{2 \mu H}{\pi(\bar{\omega}+v(t))} \cos \phi ; \\
\frac{d \phi}{d t}=\bar{\omega}-v-\left(\frac{\pi}{l}\right)^{2} \frac{V^{2}}{8 \omega}- \\
-\mu\left(\frac{2 H}{\pi(\bar{\omega}+v(t)) a} \sin \phi+\frac{3}{32} \frac{\pi^{2}}{l^{2}} \frac{a^{2}}{\bar{\omega}}\right),
\end{gathered}
$$

where $\bar{\omega}_{k}=\frac{k \pi}{l} \sqrt{\left(\frac{k \pi}{l}\right)^{2} \frac{E I}{m+m_{1}} \mp \frac{N}{m+m_{1}}}$.

The "+" sign corresponds to the stretching of the body by an axial force, and the "-" sign corresponds to compression of the body by an axial force. In Fig. 1, $a$ the dependency of the nonlinear vibration frequency on the relative velocity of the CFHM $V$ and the compression or 
stretching force is shown at $m_{1}=0.6 \mathrm{~kg} / \mathrm{m}, a=0.02 \mathrm{~m}$. In Fig. $1, b$ the dependency of the nonlinear vibration frequency from the compression or stretching force and amplitude is shown at $m_{1}=0.6 \mathrm{~kg} / \mathrm{m}$ and $V=4 \mathrm{~m} / \mathrm{s}$. These graphs show that the dominant influence on the vibration frequency change is performed by the linear velocity of the CFHM. This velocity should be considered in the first place, when investigating resonance.

In Fig. 2, the resonance curves of the vibration amplitudes are presented, at the fast crossing of the resonance point while $s=1$. The graphical dependencies in Fig. 2 correspond to the following values of the parameters: $\omega=310 \mathrm{~s}^{-1}, V=0 \mathrm{~m} / \mathrm{s},-$ case $a ; \omega=310 \mathrm{~s}^{-1}, m_{1}=$ $0.5 \mathrm{~kg} / \mathrm{m}, V=4 \mathrm{~m} / \mathrm{s}$ - case $b$.

The up-defined differential equations allow getting the formulas for determining the amplitude of stationary resonance vibrations

$$
\begin{gathered}
\frac{\beta}{m+m_{1}}(\bar{\omega})^{s-1} a^{s}-\frac{2 \mu H}{\pi(\bar{\omega}+v(t))} \cos \phi=0 \\
\bar{\omega}-v(t)-\left(\frac{\pi}{l}\right)^{2} \frac{V^{2}}{8 \omega}= \\
=\mu\left(\frac{2 H}{\pi(\bar{\omega}+v(t)) a} \sin \phi+\frac{3}{32} \frac{\pi^{2}}{l^{2}} \frac{a^{2}}{\bar{\omega}}\right)
\end{gathered}
$$

and the resonant curve

$$
\begin{aligned}
& \left(\frac{2 \mu H}{\pi(\bar{\omega}+v(t))}\right)^{2}=\left(\frac{\beta}{m+m_{1}}(\bar{\omega})^{s-1} a^{s}\right)^{2}+ \\
& +a^{2}\left(\bar{\omega}-v(t)-\left(\frac{\pi}{l}\right)^{2} \frac{V^{2}}{8 \bar{\omega}}-\frac{3 \mu}{32} \frac{\pi^{2}}{l^{2}} \frac{a^{2}}{\bar{\omega}}\right)^{2} .
\end{aligned}
$$

These facts are the main points of consideration while investigating resonance vibrations of an elastic body.

The results of the paper also show that:

- for small CFHM velocities the resonance amplitude is greater;

- for smaller linear mass of CFHM, the resonance amplitude is smaller.

The resulting mathematical model of nonlinear vibrations of an elastic shaft, and the dependencies between the parameters of the oscillatory system, obtained using asymptotic methods of nonlinear mechanics, allow choosing such elastic characteristics of the industrial equipment, that make the resonance operation regimes impossible.

\section{References.}

1. Ilin, S. R., Samusia, V. I., Ilina, I. S. and Ilina, S. S., 2016. Influence of dynamic processes in mine hoists on safety exploitation of shafts with broken geometry. Naukovyi Visnyk Natsionalnoho Hirnychoho Universytetu, 3, pp. 48-53.

2. Kyrychenko, Y. O., Samusya, V. I., Kyrychenko, V.Y. and Romanyukov, A. V., 2013. Experimental investiga-
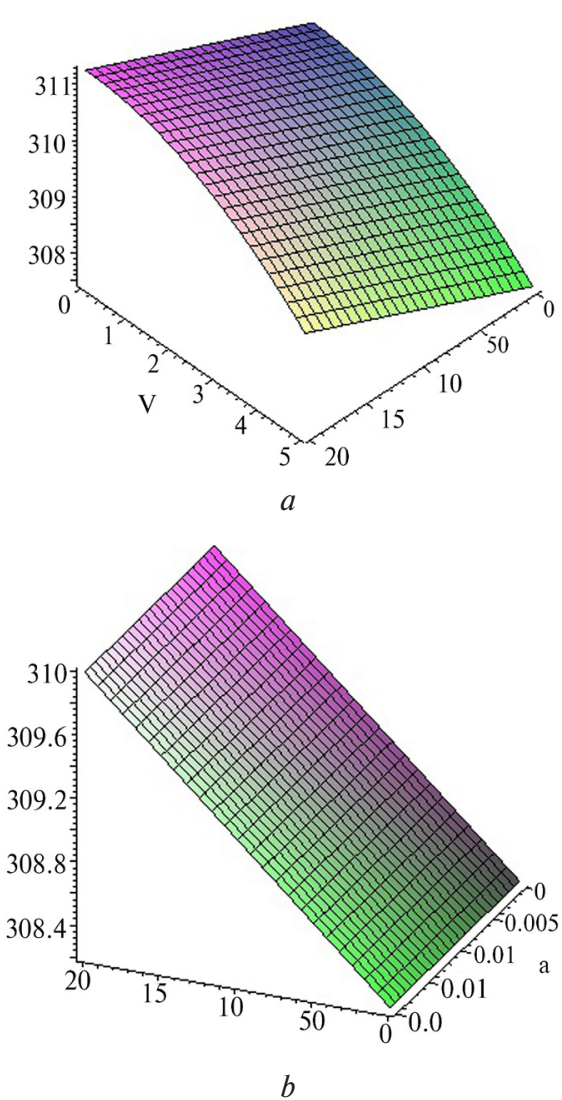

Fig. 1. The dependency of the nonlinear vibration frequency from:

$a$ - the relative velocity of CFHM and the compression or stretching force; $b$ - the compression or stretching force and the amplitude
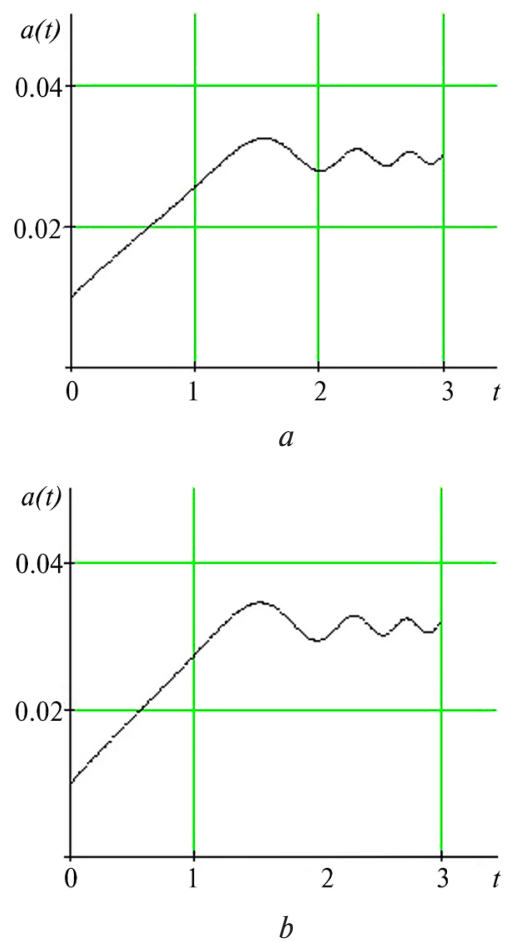

Fig. 2. Resonant curves of the vibration amplitude at various parameter values:

$a-\omega=310 \mathrm{~s}^{-1}, V=0 \mathrm{~m} / \mathrm{s} ; b-\omega=310 \mathrm{~s}^{-1}, \mathrm{~m}^{1}=0.5 \mathrm{~kg} / \mathrm{m}$, $V=4 \mathrm{~m} / \mathrm{s}$ 
tion of aero-hydroelastic instability parameters of the deepwater hydrohoist pipeline. Middle East Journal of Scientific Research, 18(4), pp. 530-534.

3. Kyrychenko, Y., Samusia, V. and Kyrychenko, V., 2012. Software development for the automatic control system of deep water hydrohoist. In: Geomechanical Processes During Underground Mining - Proceedings of the School of Underground Mining, pp. 81-86.

4. Shpachuk, V.P., 2016. Effect of mutually amplifying action of two coordinate shock loading in problems of dynamics of knots of machines. Naukovyi Visnyk Natsionalnoho Hirnychoho Universytetu, 6, pp. 89-94.

5. Pukach, P. Ya. and Kuzio, I. V., 2015. Resonance fenomena in quasi-zero stiffness vibration isolation systems. Naukovyi Visnyk Natsionalnoho Hirnychoho Universytetu, 3, pp. 62-67.

Мета. Розроблення методики знаходження резонансних режимів роботи промислового обладнання типу пружного вала, що широко використовується в гірничорудній промисловості, шляхом дослідження математичної моделі нелінійних коливань. Математичні моделі таких коливальних систем раніше в літературі досліджувалися переважно на базі чисельних і експериментальних підходів. У цій роботі пропонується за допомогою поєднання хвильової теорії руху та асимптотичних методів нелінійної механіки із застосуванням апарату спеціальних періодичних функцій дослідити динаміку коливальної системи та умови виникнення резонансних явищ у ній, а також описати методику визначення резонансних кривих з метою збільшення запасу міцності промислового обладнання.

Методика. Методика вивчення резонансних амплітуд і частот, визначення характеристик міцності обладнання базується на застосуванні асимптотичного методу нелінійної механіки, хвильовій теорії руху й використанні спеціальних Ateb-функцій.

Результати. У роботі для зазначених нелінійних коливальних систем типу пружного вала аналітично отримані умови визначення резонансних амплітуд i частот залежно від параметрів системи та описана загальна методика визначення резонансних кривих.

Наукова новизна. Полягає в тому, що вперше повний аналіз впливу фізико-механічних і геометричних чинників динамічного процесу на резонансні частоти та амплітуди в системах типу пружних валів здійснений на базі аналітичних підходів, які дозволяють, на відміну від чисельних методів та експериментальних підходів, точніше досліджувати особливості динаміки таких систем.

Практична значимість. Запропонована методика дозволяє вирішувати важливі із практичної точки зору завдання створення та оптимізації параметрів технічних коливальних систем на стадії проектування, вибирати пружні характеристики валів, розраховувати режими роботи бурильного й шнекового обладнання з урахуванням можливих резонансних явищ. Визначення резонансних режимів роботи об- ладнання, у свою чергу, дозволяє здійснювати ефективні й безпечні гірничі роботи.

Ключові слова: математична модель, нелінійні коливання, асимптотичний метод, пружний вал, резонансна крива, спеціальні функції

Цель. Разработка методики нахождения резонансных режимов работы промышленного оборудования типа упругого вала, которое широко используется в горнорудной промышленности, путем исследования математической модели нелинейных колебаний. Математические модели таких колебательных систем ранее в литературе исследовались преимущественно на базе численных и експериментальних подходов. В этой работе предлагается с помощью сочетания волновой теории движения и асимптотических методов нелинейной механики с применением аппарата специальных периодических функций исследовать динамику колебательной системы и условия возникновения резонансных явлений в ней, а также описать методику определения резонансных кривых с целью увеличения запаса прочности промышленного оборудования.

Методика. Методика изучения резонансных амплитуд и частот, определения характеристик прочности оборудования базируется на применении асимптотического метода нелинейной механики, волновой теории движения и использовании специальных Ateb-функций.

Результаты. В работе для указанных нелинейных колебательных систем типа упругого вала аналитически получены условия определения резонансных амплитуд и частот в зависимости от параметров системы и описана общая методика определения резонансных кривых.

Научная новизна. Заключается в том, что впервые полный анализ влияния физико-механических и геометрических факторов динамического процесса на резонансные частоты и амплитуды в системах типа упругих валов осуществлен на базе аналитических подходов, которые позволяют, в отличие от численных методов и экспериментальных подходов, точнее исследовать особенности динамики таких систем.

Практическая значимость. Предложенная методика позволяет решать важные с практической точки зрения задачи создания технических колебательных систем на стадии проектирования, выбирать упругие характеристики валов, рассчитывать режимы работы бурильного и шнекового оборудования с учетом возможных резонансных явлений. Определение резонансных режимов работы оборудования, в свою очередь, позволяет осуществлять эффективные и безопасные горные работы.

Ключевые слова: математическая модель, нелинейные колебания, асимптотический метод, упругий вал, резонансная кривая, специальные функции

Рекомендовано до публікації докт. техн. наук Є.В. Харченком. Дата надходження рукопису 16.11.16. 